\title{
GOOD LOCAL GOVERNANCE IN VIETNAM - BASED ON THE VIETNAM PUBLIC ADMINISTRATION PERFORMANCE INDEX IN RECENT YEARS
}

\author{
Nguyen Trong Binh \\ Dr., Faculty of School Leadership and Public Policy, \\ Academy of Politics Region IV (belonging to Ho Chi Minh \\ National Political Academy), Can Tho City, Vietnam. \\ Address: 6 Nguyen Van Cu (extension), An Binh ward, \\ Ninh Kieu district, Can Tho city, Vietnam. \\ E-mail: trongbinh195@yahoo.com.
}

\begin{abstract}
Currently, public governance theory and "good governance" have a profound and positive influence on the government reform process in many countries around the world today. In essence, good governance is the set of principles and criteria on social management to maximize public interests as well as promote and ensure the harmonious and sustainable development of a country. It can be said that good governance is both the ideal state and the goal that government reform in countries is aiming for, and the guiding principles for the design and operation of the state apparatus, government or system. In recent years, reform of government as well as reform of local government, according to good governance theory in Vietnam, has achieved many outstanding results. This is evident in the improvement in the indicators of provincial governance and public administration (Provincial Governance and Public Administration Performance Index (hereinafter referred to as PAPI)) in Vietnam over the years. Based on the survey results of PAPI in recent years, the article analyzes the good governance level of the local government of Vietnam, offers comments and assessments and proposes solutions on how to increase and strengthen the reform of local government in Vietnam according to good governance theory.
\end{abstract}

Keywords: good governance; local government; Vietnam; PAPI.

Citation: Binh, Nguyen Trong. (2021). Good Local Governance in Vietnam Based on the Vietnam Public Administration Performance Index in Recent Years. Public Administration Issues, no 5 (Special Issue I, electronic edition), pp. 73-88 (in English). DOI: $10.17323 / 1999-5431-2021-0-5-73-88$ 


\section{Introduction}

Up to now, researchers and international organizations have, provided different conceptions of "good governance". Some of the following points of view can be listed: (i) Good governance is the process of social management to maximize public benefits. Its basic feature is the collaborative management between the state and its citizens over public affairs, a new relationship between the state, the market and society (Sheng, 2007); (ii) Good governance refers to the political and institutional processes and outcomes needed to achieve development goals. It is a process by which public agencies deal with public affairs, manage public resources and ensure the realization of human rights in a way that is free from corruption, and abuse, and is in compliance with the rule of law... Depending on the context and intended use, the term "good governance" may be used to refer to such issues as: full respect of human rights; the rule of law; effective participation; multi-actor partnerships; transparent and accountable processes and institutions; efficient and effective public sector; legitimacy; access to knowledge, information and education; political empowerment of people; equity; sustainability; and attitudes and values that foster responsibility, solidarity and tolerance (OHCHR, 2018); (iii) "Good governance refers to competent, timely, comprehensive and transparent management systems..." (Clark, 2011); (iv) Good governance is a set of transparent, accountable, capable and skilled institutions, along with the determination to do good... All of which help a state provide effective public service to the people" (Wolfowitz, 2006); (v) Good governance is demonstrated through four basic factors: accountability, participation, predictability, transparency (ADB, 1995); (vi) Good governance is based on five principles: openness, participation, accountability, effectiveness and coherence (EC, 2001); (vii) Good governance is reflected in factors such as transparency in state operations, efficiency in managing public resources, and the stability and transparency of the legal and economic environment.... (Camdessus, 1997); (viii) According to the Organization for Economic Cooperation and Development, the key elements of good governance include: accountability, transparency, efficiency, effectiveness, responsiveness, forward vision and rule of law (OECD).

The aforementioned views on good governance also present a consensus on some key features of good governance. According to a United Nations document, good governance includes major characteristics, namely: participatory, consensusoriented, accountable, transparent, responsive, effective, efficient, equitable and inclusive, and follows the rule of law (United Nations ESCAP). Yu Keping said that good governance has ten basic characteristics such as: (i) legitimacy; (ii) the rule of law; (iii) transparency; (iv) accountability; (v) responsiveness; (vi) efficiency; (vii) participation; (viii) stability; (ix) integrity; (x) social justice (Ping, 2000). There is also a view that good governance includes features, such as: participatory, the rule of laws, transparent, responsive, consensus, equitable and inclusive, effective, and accountable (Binh, Le Hai, 2020).

Since 2009, the Centre for Community Support and Development Studies (CECODES), the United Nations Development Program (UNDP) in Vietnam, the Center for Personnel Fostering and Scientific Research of Vietnam Fatherland 
Front (VFF-CRT) and the Real-time Analysis Company (RTA) have coordinated to implement the Provincial Governance and Public Administration Performance Index (PAPI) program. PAPI is a governance quality assessment program of local government in Vietnam over the years. The purpose of PAPI is to improve the efficiency of service provided by the local government in order to better meet the increasing demands of the public by: (i) creating opportunities for citizens to participate in the assessment efficiency of the government's activities, and mobilizing the government to improve the ways it serves the public; (ii) promote self-assessment to innovate, create healthy competition practices and a culture of learning from local governments. The content of the program focuses on surveying, and collecting data and opinions on the following contents: (i) Participation at Local Levels; (ii) Transparency; (iii) Vertical Accountability; (iv) Control of Corruption; (v) Public Administrative Procedures; (vi) Public Service Delivery; (vii) Environmental Governance; (viii) E-Governance. Each of these has a rating scale from 1 to 10 points. To carry out this assessment program, PAPI conducted direct interviews with the public. By the end of 2019, PAPI had collected and reflected the experiences of 131,501 people. In 2019, PAPI directly interviewed 14,138 people in all 63 provinces and in cities nationwide (CECODES, VFF-CRT, RTA \& UNDP, 2020). The aforementioned evaluation contents have not covered all the characteristics of good governance, but have included some very basic contents of good governance, such as participation, transparency, effectiveness and efficiency. Therefore, the PAPI results partly reflect the good governance of the local government in Vietnam. Based on PAPI's sources from 2011 to 2019, this study analyzes the good governance of local government in Vietnam, provides comments, and reviews, and suggests recommendations to promote reform of local government in Vietnam under good governance.

\section{Good Governance of Local Government in Vietnam from 2011 to the present}

\section{Participation at Local Level}

Citizen participation is a fundamental feature of democratic governance, and is also one of the key features of good governance. Therefore, the breadth and depth of people's participation are important criteria for assessing the level of democracy and democratic governance (Cohen, 1971). In order to assess people's participation in local governance, PAPI has surveyed and captured people's experiences in various aspects, such as: (i) Civic Knowledge (people's understanding of current books and leadership positions); (ii) Opportunities for Participation (level of participation in socio-political organizations, social organizations, people's clubs, and rate of participation in the last election); (iii) Quality of Elections (ensuring principles such as competition, autonomy, and transparency in the election); (iv) Contributions (the level of people's voluntary contributions to public work in a commune, residential area, etc).

Accordingly, in 2011, the average score of grassroots citizen participation nationwide was 5.23 points on a scale of 1 to 10 . Of this 5.23 Civic Knowledge 
is 1.11 points; Opportunities for Participation is 1.88 points; Quality of Elections is 1.45 points; and Contributions is 0.85 points (CECODES, VFF-CRT, RTA \& UNDP, 2012). The average scores of Participation at Local Levels in 2012, 2013, 2014, 2015, 2016, 2017, 2018 are respectively: 5.16; 5.14; 4.91; 4.71; 5.15; 5.18, 5.19 on a scale of 1 to 10. In 2019, the overall average score of Participation at Local Levels was 4.84 points on a scale of 1 to 10 . Of this, Civic Knowledge is 0.74 points; Opportunities for Participation is 1.46 points; Quality of Elections is 1.48 points; and Contributions is 1.16 points. The locality with the lowest score in this content is Phu Yen province with 4.11 points (scale of $1-10$ ). The locality with the highest score in this content is Ha Tinh province with 5.81 points (CECODES, VFF-CRT, RTA \& UNDP, 2020).

\section{Transparency}

Publicity and transparency of information in government activities is of great importance. This is the basis to ensure citizens' right to know. Implementation of information disclosure and transparency is also the basis to ensure the participation of the people and is an important way to sanction unconstitutional behavior of public power. Kenneth Culp Davis argues that: "Publicity is the natural enemy of autocratic tyranny, also a natural ally to combat injustice" (Kenneth Culp Davis, 1970); the secret itself, like evil, is an instrument of conspiracy, a cause of inequality; Publicity is the essence of democratic politics, the more material that is disclosed, the better the public good is (Norman Marsh, 1987). Therefore, information transparency is one of the key features of good governance.

Over the past years, PAPI has surveyed and assessed the level of information disclosure by local authorities in Vietnam through the following indicators: (i) access to information (channels of access to information of people and their effectiveness); (ii) Poverty Lists; (iii) communal Budget and Expenditure; (iv)LandUse Plans/Price Frames. Accordingly, the national average score for transparency in 2011 was 5.47 points on a scale from 1 to 10 . Of this, access to information is 2.15 points; poverty Lists is 1.76 points; and communal Budget and Expenditure is 1.56 points (CECODES, VFF-CRT, RTA \& UNDP, 2012). From 2012 to 2018 , the national average score for transparency was: $5.61 ; 5.80 ; 5.74 ; 5.29$; $5.55 ; 5.68$ and 5.19 on a scale of $1-10$ points. By 2019 , the overall national average score for publicity and transparency was 5.35 points. The locality with the lowest score is Phu Yen (4.11 points), the locality with the highest score is HoaBinh (5.66 points) (CECODES, VFF-CRT, RTA\& UNDP, 2020).

\section{Vertical Accountability}

Democratic politics as well as democratic governance and good governance especially emphasize the accountability of the government as well as the bureaucracy of public service. Usually, governments need to fulfill their political, legal, administrative and ethical responsibilities. In which case, responsiveness is a core requirement for a responsible government. Response means that the government fully and promptly grasps the legal and legitimate needs and aspirations of citizens as well as take timely and effective measures to meet legal needs. The assessment of the accountability of local government to the people partly reflects the 
responsiveness and accountability of the government. In order to assess accountability to the people of local government, over the years, PAPI has conducted a survey of key aspects, such as: (i) Interactions With Local Authorities (assess ways for people to contact the authorities and their effectiveness); (ii) Local Government's Response to Citizens' Appeals (assessing the extent to which people send complaints and denunciations, reporting to the authorities and the government's response to complaints and denunciations; (iii) Access to Justice Services (surveying people's confidence in judicial agencies, especially local courts).

The PAPI survey results show that, in 2011, the national average score for accountability was 5.50 points on a scale of 1-10 (CECODES, VFF-CRT, RTA \& UNDP, 2012). In the years from 2012 to 2018, the national average score for accountability was respectively: $5.58 ; 5.65 ; 5.73 ; 5.46 ; 4.85 ; 5.02 ; 4.89$ on a scale of 1-10. In 2019, the score of accountability of localities across the country ranged from 4.30 points (Vinh Long province) to 5.59 points (Quang Binh province). The overall national average of accountability is 5.15 points on a scale of $1-10$ (CECODES, VFF-CRT, RTA \& UNDP, 2020).

\section{Control of Corruption}

Integrity is one of the key characteristics of good governance. It reflects the level of purity of government as well as public servants. One indicator for determining the level of integrity is the level of corruption in the public sector. Usually the higher the level of corruption, the lower the integrity level; on the contrary, the lower the level of corruption, the higher the degree of integrity. Therefore, it can be said that the assessment of corruption control in the public sector is also an assessment of the level of integrity of the public sector. Over the years, to assess corruption in the public sector (or measure the integrity of local governments and public service organizations), PAPI has captured people's opinions on: (i) Limits on Public Sector Corruption (surveying the extent to which people need to spend more money in the process of local government handling administrative procedures); (ii)Limits on Corruption in Service Delivery (surveying the extent to which people need to spend extra money in health care and education); (iii) Equity in Employment (surveying the extent to which people have to spend "hand-to-hand" money to get jobs in state agencies); (iv) Willingness to Fight Corruption (surveying people's perceptions of seriously handling corruption cases in the locality).

The survey results of PAPI showed that, in 2011, the average score of localities across the country achieved in this content was 5.76 points on a scale of 1-10. Of this, Limits on Public Sector Corruption is 1.40 points; Limits on Corruption in Service Delivery is 1.76 points; Equity in Employmentis is 0.94 points; and Willingness to Fight Corruption is 1.66 (CECODES, VFF-CRT, RTA \& UNDP, 2012). From 2012 to 2018, the average scores of localities in this content were $5.90 ; 6.15 ; 6.11 ; 5.75 ; 5.69 ; 6.09$ and 6.57 points respectively on a scale of 1-10. In 2019, the average score of localities across the country in this content ranged from 5.44 points (Hai Phong city) to 8.19 points (Ben Tre province). The national average score is 7.2 points on a scale of $1-10$ points (CECODES, VFF-CRT, RTA \& UNDP, 2020). 


\section{Public Administrative Procedures}

A core feature of good governance is "citizen-centered government governance". Citizen-centered government governance is manifested in many ways, one of which is that the government ensures sufficient quantity and quality of public service delivery to the population. Administrative procedure is considered a kind of public service. Therefore, the survey and evaluation of the settlement of administrative procedures by the local government not only show the results in administrative procedure reform, as well as the quality of activities of local governments, but also reflect the level of "citizen-centered" in the governance of local governments. Over the past years, PAPI has taken the assessment and survey of the provision of administrative procedures by the local government as one of the contents of the quality assessment and governance capacity. Public administrative procedures are quite wide in scope. PAPI only survey and evaluate the settlement of a number of administrative procedures directly related to many people, namely: (i) Certification Procedures (surveying the extent to which the people have gone through the certification procedures, the authority's certification, the quality of the certification service, the government's certification and their satisfaction level); (ii) Construction Permit (surveying people's perceptions in the construction permit application process and their satisfaction level); (iii) Land Procedures (surveying people's perceptions in the process of applying for land use rights certificates and their level of satisfaction); (iv) Personal Procedures (assessing people's perception about the quality of administrative services provided by commune authorities).

The survey results of PAPI show that, in 2011, the average score of localities across the country in this content was 6.88 points on a scale of $1-10$. Of this 6.88 , the score for Certification Procedures is 1.68 points; the score for Construction Permit is 1.77 points; the score for Land Procedures is 1.58 points; and the score for Personal Procedures is 1.84 points (CECODES, VFF-CRT, RTA \& UNDP, 2012). From 2012 to 2018 , the average score achieved by localities across the country was $6.87 ; 6.89 ; 6.88 ; 6.79 ; 7.10 ; 7.17$ and 7.39 points respectively on a scale of $1-10$. In 2019, the average score of localities in this content ranges from 6.84 points (Khanh Hoa province) to 7.67 points (Tra Vinh province). The national average score is 7.34 points on a scale of $1-10$ (CECODES, VFF-CRT, RTA \& UNDP, 2020).

\section{Public Service Delivery}

As mentioned above, the quality of public services is an important criterion for evaluating the governance output of local governments and also an important criterion for evaluating the governance effectiveness and quality of the government local. Therefore, the assessment of the quality of public services is also an important aspect to reflect the level of "good governance" of the local government. Over the years, the assessment of public service quality has been conducted by PAPI on component contents, such as: (i) Health (including the proportion of people participating in health insurance, use of health insurance cards, free medical care services for children under 6 years old, quality hospitals at district level, etc.); (ii) Education (including walking distance to school $(\mathrm{km})$, time to get to school (minutes), comments on teaching quality of public primary schools, quality of primary schools in the 
commune); (iii) Infrastructure (including the proportion of households using electricity from the grid, the proportion of respondents saying that the household has not had a power cut in the past 12 months, the type of road closest to the household), the frequency of waste collection services by local authorities, proportion of people using tap water, proportion of households using unsanitary water); (iv) Law and Order (including aspects such as the level of safety, order in the area in which you live, a change in security in a better direction, a sense of safety when the walking alone during the day, feeling safe when walking alone at night, etc.). PAPI's research results in this component index over the past years show that in 2011 the average score in this content of the local government across the country was 6.75 points on a scale of 1-10. Of this, the average score of the four above-mentioned components is respectively $1.75 ; 1.65 ; 1.75$ and 1.60 points (CECODES, VFF-CRT, RTA \& UNDP, 2012). From 2012 to 2018, the overall average score in this content of the local authorities across the country were respectively: $6.90 ; 6.95 ; 7.02 ; 7.04 ; 7.10$; 7.15 ; and 7.10 on a scale of $1-10$. In 2019, the average score in this index of local authorities across the country ranged from 6.88 points (Tien Giang province) to 7.88 ( $\mathrm{Da}$ Nang city) on a scale of $1-10$. The average score of the localities is 7.24 (CECODES, VFF-CRT, RTA \& UNDP, 2020).

\section{Environmental governance}

The effectiveness of local government environmental governance is directly and in many ways related to the quality of life of the people. The quality of the environment reflects the quality of public services and also reflects the level of implementation of local governments' commitment to promoting sustainable development. Therefore, since 2018, CECODES, VFF-CRT, RTA \& UNDP have added the component index of environmental governance of the local government to the PAPI. The addition of this criterion reminds all parties, especially local authorities, of the need to attach importance to improving environmental governance efficiency in order to improve the quality of life of the people as well as promote sustainable development. The environmental governance assessment has been conducted by PAPI on the component criteria, such as: (i) Seriousness in Environment Protection (mainly surveying the percentage of people who say local enterprises give bribes to avoid the obligation to protect the environment); (ii) Quality of Air (in terms of proportion of respondents reporting not having to wear a mask to avoid air pollution while traveling locally; proportion of respondents reporting local air quality) and adequate living place; and proportion of respondents saying that the local air quality is better than 3 years ago); (iii) quality of water (water from rivers /canals/streams close to home is clean enough for drinking, water from rivers/canals/streams near the house is clean enough for laundry, and water from rivers/canals/streams clean enough and close to home for swimming). PAPI's survey results show that in 2018 the average score in the environmental governance index across the country is below average, with 4.63 points/a scale of 1-10 points. Of this, Seriousness in Environment Protection is 1.97 points; quality of air is 1.99 points; and quality of water is 0.67 points. The scores achieved by provinces/cities ranged from 3.54 to 6.74 points (on a scale of 1 to 10) (CECODES, VFF-CRT, RTA \& UNDP, 2019). In 2019, the average 
score of the content index for environmental governance in localities nationwide ranged from 2.71 points (Thai Nguyen province) to 4.94 points (Dong Thap province). The national average score is 3.53 on a scale of $1-10$ (CECODES, VFF-CRT, RTA \& UNDP, 2020).

\section{E-governance}

The development of information technology, the internet and the advent of the "big data age" have created favorable conditions to increase e-government construction. Increasing the application of information technology in local government activities is significant in many aspects, such as improving the efficiency of government activities; providing information to people; capturing opinions, recommendations and the reflections of people; promoting people's participation and supervision; and providing public services to the people; and timely interaction with the public (Binh, Nguyen Trong, 2020). In other words, the electronicization of government plays a role in building a democratic, transparent, accountable, efficient and equitable government. Therefore, improving the e-governance efficiency of local governments contributes to good governance. Since 2018, CECODES, VFF-CRT, RTA \& UNDP have added an electronic governance criterion to the PAPI. The criteria for assessing the e-governance of local governments include: (i) Access to E-government Portals (surveyed on all aspects, such as the proportion of respondents who reported having obtained enough information, instructions and forms to be taken from the local authority's web portal when authenticating, certifying, completing construction licensing procedures and issuing land use right certificates); (ii) Access to the Internet (surveyed in various aspects, such as the proportion of people accessing domestic news via the internet; proportion of people reporting internet connection at home); (iii) E-Reponsiveness (proportion of respondents who submitted questions to local authorities through the "online question and answer" section on the portal; and percentage of respondents received responses from local government after submitting questions via the "online question and answer" section). The results of the PAPI survey in 2018 showed that the average score of localities was sent to the "online question and answer" section. Achievements in this index ranged from 1.93 points (Quang Ngai province) to 4.24 points from a scale of 1-10 (Da Nang city). The national average score is 2.99 points (CECODES, VFF-CRT, RTA \& UNDP, 2019). In 2019, the average score achieved by localities in the e-governance index ranged from 2.05 points (Quang Ngai province) to 5.00 points on a scale of $1-10$ points (Da Nang city). The national average score is 3.30 points (CECODES, VFF-CRT, RTA \& UNDP, 2020).

\section{Synthesized results on good governance of local governments from 2011 to 2019}

The PAPI survey results not only reflect the change in the component indicators, but also the aggregate results of the performance of governance and public administration at the provincial level (or good governance of the local government) in Vietnam from 2011 to 2019. Accordingly, the determination of the aggregate results of the effectiveness of the governance and public administration at the provincial level is done by adding scores of six original indexes in each 
year, excluding the two component indicators of environmental governance and e-governance added from 2018. The results show that the aggregate score of good governance of local authorities in Vietnam since 2011 to 2019 respectively: 34.5 points; 35.5 points; 35.4 points; 35.3 points; 34.0 points; 35.1 points; 35.9 points; 36.5 points and 37.4 points on a scale of 10 to 100 (CECODES, VFF-CRT, RTA \& UNDP, 2020).

\section{Discussion}

From the PAPI survey results, we can draw some comments and assessments of the good governance of local authorities in Vietnam over the years as follows:

Firstly, although it is not stable, through the aggregate score of the six original sub-indexes on the efficiency of governance and the public administration at the provincial level, especially comparing the total score in the six sub-indexes of 2011 and 2019, it can be seen that the good governance of local governments in Vietnam has been improved, from 34.5 in 2011 to 37.4 points in 2019 (from a scale of 10 to 100). This both reflects the positive change in governance of local governments in Vietnam in the past, and also shows the initial results in governance reform of local governments in Vietnam over recent years.

Secondly, although there is an improvement and inequality in indicators (some are not high, some are relatively good), in general the quality of governance and public administration at the provincial level or the level of good governance is still not high, if not low. The point is that, if only six original component indexes are included, excluding two additional component indexes from 2018, the combined score achieved in 2019 is only 37.4 points on a scale of 10-100. If the eight indexes are included, the score achieved is below average, with 44.92 points on a scale of $10-100$. That means, reforming local government according to good governance in Vietnam still has a lot of room for maneuverand still has much to do; at the same time, in the coming years, Vietnam needs to place a focus on governance innovation of local governments.

Thirdly, in the component indicators of PAPI, such as control of corruption, Public administrative procedures and Public Service Delivery have improved significantly over the years, and at the same time these are also the indicators with the best scores. Specifically, for the corruption control index in the public sector, if in 2011 the score was 5.76 from a scale of 1-10, in 2019 the score was 7.2 points. For public administrative procedures, if in 2011 the score was 6.88 from a scale of 1-10, in 2019 the score was 7.34. For Public Service Delivery, if in 2011 the score was 6.75 from a scale of 1-10 points, in 2019 the score was 7.24 points. If compared with other indexes at the same time, these indexes have higher scores. Specifically, in 2019, scores of indicators on control of corruption, public administrative procedures, and Public Service Delivery are 7.2, 7.35, and 7.24 points respectively (out of 10 points). This is proportional to the Government's determination to improve these indicators. At the same time, the determination and efforts of the Government of Vietnam in the prevention and fight against corruption, in reforming administrative procedures and improving the quality of public services have brought about positive results. 
Fourthly, in the component indicators, those such as Participation at Local Levels, transparency, and Vertical Accountability have not been improved; the score actually tends to decrease. At the same time, these are also component indicators with low scores. Specifically, in 2011, the number of points achieved in the component indicators, such as Participation at Local Levels, transparency and Vertical Accountability were 5.23, 5.47 and 5.50 points respectively (on a scale of 1-10). By 2019, the scores of these component indicators will not only increase, but also decrease. Specifically, the score of the component indicators, such as Participation at Local Levels, transparency, Vertical Accountability were 4.84, 5.35 and 5.15 respectively (on a scale of 1-10) (CECODES, VFF-CRT, RTA \& UNDP, 2020).

Regarding Participation at Local Levels, the PAPI report in 2018 showed that on Civic Knowledge, $40.73 \%$ of the respondents said that they know about local leaders; on Opportunities for Participation, $16.76 \%$ of respondents said that they participate in social organizations, groups, and independent clubs; on Voluntary Contributions, $45.24 \%$ of the respondents said that they have participated in voluntary contributions; the percentage of respondents who said that they had contributed their opinions in the design process to renew/repair the project is $34.01 \%$; and $5.44 \%$ of the respondents said that they had the opportunity to comment on the local land use planning and plan (CECODES, VFF-CRT, RTA \& UNDP, 2019). By 2019, the above-mentioned indexes had the corresponding rates of $13.40 \% ; 15.49 \% ; 47.18 \% ; 36.19 \%$ and $4.54 \%$ respectively (CECODES, VFF-CRT, RTA \& UNDP, 2020).

Regarding transparency, the PAPI report in 2018 showed that $11.83 \%$ of respondents said they had received policy and legal information from the local authorities; $12.64 \%$ of respondents said that the information received was useful; and $12.59 \%$ of respondents said that information about policies and laws from authorities is reliable. In 2019, the respective indexes mentioned above had the rate of $11.5 \% ; 11.72 \% ; 11.48 \%$ respectively. The PAPI report in 2018 showed that the proportion of respondents saying that commune/ward budget revenues/ expenditures were publicly announced was $40.98 \%$; the rate of respondents saying that they have read the budget revenue and expenditure statistics table is $27.65 \%$; and the rate of respondents knowing about current land use planning and plans in the locality is $18.39 \%$ (CECODES, VFF-CRT, RTA \& UNDP, 2019). By 2019, these indices had the respective ratios of: $40.55 \% ; 28.76 \% ; 16.87 \%$ respectively (CECODES, VFF-CRT, RTA \& UNDP, 2020).

Regarding Vertical Accountability, the PAPI 2018 report showed that 25.9\% of respondents said that they sent recommendations, denunciations, denunciations and complaints to the authorities, of which $21.89 \%$ said that the authorities had responded satisfactorily to their recommendations, denunciations and denunciations. By 2019, 24.24\% of respondents said that they had sent recommendations, denunciations, denunciations and complaints to the authorities, of which $20.17 \%$ said that the authorities had responded satisfactorily. This means that measures taken to increase the participation of the people, and promote transparency and public accountability, have yielded unsatisfactory results. Therefore, it is necessary to make an overall assessment and identify the correct causes to have more effective solutions to improve the score on these indicators. 
Fifthly, among the component indicators of PAPI in 2018 and 2019, e-governance and environmental governance have the lowest scores. PAPI's survey results show that, in the years 2018 and 2019, the average scores in the environmental governance index in the localities were only 4.63 and 3.53 points respectively (on a scale of 1-10). The e-governance index in these two years is 2.99 and 3.30 points respectively. In terms of e-governance, the PAPI report in 2018 showed that the percentage of respondents who said that they had obtained instructions and forms to be performed from the local portal when authenticating and certifying is $3.48 \%$. The rate of respondents saying that they have taken information, instructions and forms to be done from the local portal when completing construction permit procedures is $0.83 \%$. The rate of respondents saying that they have taken instruction information and required forms from the local portal when completing procedures for land use right certificate is $1.35 \%$. The proportion of respondents who reported submitting their questions/requests via the online inquiry channel on the portal of the local government is $1.56 \%$ (CECODES, VFF-CRT, RTA \& UNDP, 2019). By 2019, the aforementioned rates will be $3.07 \%$; $0.77 \% ; 1.04 \% ; 1.58 \%$ respectively (CECODES, VFF-CRT, RTA \& UNDP, 2020). Regarding environmental governance, the PAPI report in 2019 showed that the percentage of people who said that local businesses did not give bribes to evade environmental protection obligations was $57.83 \%$; the rate of people saying that the competent authorities have solved the environmental problems they announced is $52.21 \%$; the proportion of respondents saying that they do not have to wear a mask to avoid air pollution while traveling in the residential area is $37.81 \%$; the rate of respondents who think that the local air quality is better than 3 years ago is $38.16 \%$; and the proportion of respondents saying that water from rivers/canals/streams near their houses is clean enough for swimming is $16.93 \%$ (CECODES, VFF-CRT, RTA \& UNDP, 2020). This shows that improving the effectiveness of environmental governance and e-governance is the problem facing the local government in Vietnam today. In the coming years, the Government should attach more importance to the issue of improving local e-governance and environmental governance on its agenda.

\section{Some recommendations}

The above analysis shows that, although the initial results have been achieved in the reform of the local government to improve the quality of service to the public, the reform and renewal of the local government under good governance of the government localities in Vietnam still have a lot to do. To promote good governance of local governments in Vietnam, some of the following issues need to be considered:

Firstly, persistence and efforts to reform and renovate local government according to good governance theory. Moore believes that the ultimate purpose and mission of government (including local government) and public management is to create public value for society (Moore, 1995). Many researchers believe that in order for governance to create public value and promote the realization of the public good, government reform needs to take good governance theory as the ba- 
sis and basic orientation (Binh, Nguyen Trong, 2017). In the case of Vietnam, it is necessary to continue studying good governance theory as well as learning through training and retraining to make politicians, managers and civil servants in the public sector understand the characteristics of good governance. From that, it sets out the vision and measures to strengthen the innovation of the government and local governments under good governance.

Secondly, "citizen-centered" in government and local governance. It can be said that citizenship or "citizen-centered" is the basic characteristic of good governance. Having citizens in the center of governance means that the government itself is not the end, but the government is the instrument. The only plausible reason for the existence of government is in ensuring and enhancing the human dignity of its citizens; the responsibility of the government is to ensure the realization of citizens' political, economic, cultural and social interests, to satisfy the basic needs of citizens, especially the basic needs of disadvantaged groups; providing basic public services, thereby making citizens' lives better and better (Fu, 2014). This means that the government as well as local authorities need to clearly see their responsibility and mission to ensure and promote human rights and citizenship; realizing that the planning and implementation of all mottos, policies and all jobs must come from citizens, must be for the benefit of citizens; wholeheartedly serving citizens; perform well, maintain well, develop well the most basic interests of citizens, get citizens' support or disapproval, agree or disagree, happy or unhappy, satisfaction or dissatisfaction is the basic criterion for evaluating all jobs.

Thirdly, add evaluation criteria to promote reform and renewal of local government according to good governance. It can be said that local government governance is considered "good governance" when it fully demonstrates features, such as (i) citizen-centered; (ii) legality; (iii) openness and transparency; (iv) participation of the people; (v) efficiency; (vi) rule of law; (vii) responsibility; (viii) responsiveness; (ix) social justice; (x) integrity; (xi) stabilization. The assessment criteria for the governance quality of local government implemented by PAPI in recent years, although showing some characteristics of good governance, still lacks some important content and criteria important. Therefore, in order to promote reform and innovation of local governments in Vietnam under good governance, it is necessary to add the following criteria to the set of criteria for evaluating the governance quality of local governments. Accordingly, this set of evaluation criteria can include: (i) the legitimacy or confidence of people in the government; (ii) level and effectiveness of ensuring human rights and citizenship; (iii) quality of public services (public administrative procedures, quality of education services, health care, transport infrastructure, law and order, environmental governance, etc.); (iv) degree of disclosure and transparency of information; (v) citizen participation; (vi) rule of law; (vii) social justice; (viii) efficiency; (ix) accountability; (x) responsiveness; (xi) integrity (controlling corruption in the public sector); (xii) electronic governance; (xiii) degree of decentralization and decentralization to subordinates; (xiv) stability. It is necessary to develop specific component criteria to evaluate the above basic criteria (Binh, Nguyen Trong, 2019). 
Fourthly, using the efficiency of governance and public administration at the provincial level or the good level of governance of the local government as one of the core criteria in evaluating the effectiveness of leadership and management of local leaders. The innovation promotion effect of local government under good governance is fully promoted only when stakeholders attach importance to the use of assessment results; at the same time using this assessment as a basis to evaluate leaders and local leaders. Over the years, many localities in Vietnam have attached importance to using the assessment results of PAPI to serve up the content and reform program for each period. However, the government as well as many local governments have not used the assessment results of PAPI as one of the criteria in evaluating the leadership effectiveness of leaders in localities. Therefore, it is necessary to take the efficiency of governance and public administration at the provincial level in each year and each period as one of the basic criteria in assessing leaders and leaders in localities.

Fifthly, properly and fully assess the cause of the limitations to formulate effective strategies, strategies and measures to improve the low component indicators. Component indicators such as citizen participation, transparency, and accountability are key and core indicators of good governance, but are slowly being improved and the score is low. Therefore, it is necessary to properly and fully assess the causes to take effective measures to improve these component indicators. Besides, e-governance and environmental governance are currently ineffective. Therefore, it is necessary to have appropriate strategies and policies to improve the effectiveness of e-governance and local environmental governance. It should be emphasized that effective e-governance is directly related to promoting good governance by local governments. Therefore, the central and local governments need to adopt many solutions to improve the efficiency of e-governance, especially attaching importance to investment in developing e-government at the grassroots level, increasing training and fostering information technology for both public managers and citizens.

Sixthly, decentralizing strong powers to subordinates and improving the quality of the contingent of civil servants. Power concentrated at higher levels not only easily leads to the phenomenon of "running" and "asking - giving", but also it is not conducive to promoting the initiative and creativity of subordinates. Therefore, it is necessary to strengthen decentralization towards decentralization to empower autonomy and improve governance efficiency of local governments. Besides, the quality of public managers is also a decisive factor to the effectiveness and quality of governance. Therefore, many reform measures need to be adopted to improve the quality of the contingent of public managers. In order to improve the quality of the contingent of public managers, it is important to attach importance to the building of public service ethics. That is, through the work of education, organization, administration, inspection, monitoring, screening and handling to minimize the phenomenon of anticultural politics and anti-ethics public service in government agencies, as well as making the values and norms of public service ethics such as public service, public interests, public responsibility, transparency, democracy, etc., penetrate and diffuse into magistrate relations and activities. 
Seventhly, develop citizenship and civic spirit. Citizen participation is the core of democratic governance, it is also an indispensable requirement and characteristic of good governance. For good governance of local government, it requires not only efforts from the government, but also the companionship and efforts of the citizens. To meet this requirement, it is necessary to form and develop a "political culture of the participants" in the people. In other words, it is the sense of participation and civic spirit of the people. In public governance, the civic spirit of the people includes a number of aspects: (i) citizens know their rights and obligations in accordance with the law; (ii) citizens actively exercise and exercise their rights in practice; (iii) citizens are interested in and actively participate in related work in local governance; (iv) the citizen has a certain capacity to judge and evaluate whether a particular policy or behavior of the local government is with the law and the public interest; (v) citizens value, respect and protect the interests of the community; (vi) citizens have the courage to fight unlawful conduct that harms the legitimate interests of others; (vii) citizens respect the diversity of opinions, objectivity and reason in assessing things and phenomena; (viii) citizens know how to use peaceful methods to resolve conflicts and differences. Citizenship is one of the conditions to promote good governance of local governments. The status and spirit of citizenship should regulate the self-participation of citizens in local governance; regulations should be the voluntary dedication and contribution of people to common works and should promote the autonomy and self-governance of the people in local governance. The motivations and purposes of citizen participation should also be specified. At a larger level, the education of civic consciousness and spirit is conducive to establishing the civic ethics system; this is conducive to promoting democratization and publicizing the workings of public power as well as for building a harmonious society. Due to the importance of citizenship, to promote good governance of local governments, it is necessary to attach importance to fostering and educating citizenship for the people. Under the current conditions of Vietnam, there should be a project on education and the improvement of ethics and civic responsibility. On the other hand, educating and improving citizenship should be seen as an important responsibility of the local government (Binh, Nguyen Trong et al., 2020).

\section{Conclusion}

As one of the most prestigious local government governance quality assessment programs in Vietnam today, over the years, the PAPI has shown a fairly full level of governance quality as well as good governance of the local government. On the other hand, this also contributes to promoting innovation and reform of local government in Vietnam under good governance. The PAPI survey results show that, in general, the good governance of local authorities in Vietnam has improved, but is still not high. Therefore, to meet the development requirements of Vietnam in the coming years, Vietnam needs to continue to strengthen its institutional reforms as well as put the governance innovation of local governments under good governance in an appropriate position on its agenda. 


\section{REFERENCES}

1. ADB (1995). Governance: Sound Economic Management (August), pp. 3, 4, 8.

2. Binh, Le Hai. (2020). Some Theoretical and Practical Issues About National Governance in the Prevention and Control of the COVID-19 Pandemic in Vietnam. Journal of Political Theory, no 6.

3. Binh, Nguyen Trong. (2020). Social Governance Innovation in Some European Countries and Some Governance for Vietnam. European Studies, no 10.

4. Binh, Nguyen Trong. (2017). The Theory of Public Value Management and Method for Public Administration to Well Provide Public Value. Legislative Studies, Legis No 16/2017.

5. Binh, Nguyen Trong. (2019). Some Theoretical Issues on Public Governance Assessment. State Organization Review, no 10.

6. Binh, Nguyen Trong \& Phuong, Nguyen Hoang. (2020). Study on People's Participation in the Building of New Rural Areas in the Mekong River Delta of Vietnam. Palarch's Journal of Archaeology of Egypt/Egyptology, vol. 17, no 7.

7. Camdessus, M. (1997). IMF Managing Director, Address to the United Nations Economic and Social Council, 2 July.

8. CECODES, VFF-CRT, RTA \& UNDP (2012). The 2011 Viet Nam Governance and Public Administration Performance Index (PAPI): Measuring Citizens' Experiences. A Joint Policy Research Paper by the Centre for Community Support and Development Studies (CECODES), Centre for Research and Training of the Viet Nam Fatherland Front (VFF-CRT), Real-Time Analytics, and United Nations Development Programme (UNDP). Ha Noi, Vietnam. Available at:http://papi.org.vn/bao-cao/? year-report=2011 (accessed: 26 April 2021).

9. CECODES, VFF-CRT, RTA \& UNDP. (2020). The 2019 Viet Nam Governance and Public Administration Performance Index (PAPI): Measuring Citizens' Experiences. A Joint Policy Research Paper by the Centre for Community Support and Development Studies (CECODES), Centre for Research and Training of the Viet Nam Fatherland Front (VFF-CRT), Real-Time Analytics, and United Nations Development Programme (UNDP). Ha Noi, Vietnam. Available at: http://papi.org.vn/bao-cao/?year-report=2019 (accessed: 26 April 2021).

10. CECODES, VFF-CRT, RTA \& UNDP (2019). The 2018 Viet Nam Governance and Public Administration Performance Index (PAPI): Measuring Citizens' Experiences. A Joint Policy Research Paper by the Centre for Community Support and Development Studies (CECODES), Centre for Research and Training of the Viet Nam Fatherland Front (VFF-CRT), Real-Time Analytics, and United Nations Development Programme (UNDP). Ha Noi, Vietnam. Available at: http://papi.org.vn/bao-cao/?year-report=2018 (accessed: 26 April 2021).

11. Clark, H. (2011). Administrator of the United Nations Development Program, at the Fourth United Nations Conference on the Least Developed Countries High Level Interactive Thematic Debate on Good Governance at All Levels. Istanbul, 11 May.

12. Cohen, C. (1971). Democracy. University of Georgia Press.

13. Davis, K.C. (1970). Description Just. Baton Rouge: Louisiana State University, p. 97. 
14. EC (2001). European Governance: A White Paper. Brussels, 25 July, fn. 1 on p. 8, p. 10 (sic).

15. Fu, Zhang Cheng. (2014). On Open Government. Journal of Renmin University of China, no 5 .

16. Moore, H. (1995). Creating Public Value: Strategic Management in Government. Cambridge, MA: Harvard University Press.

17. OHCHR (n/d). About Good Governance, Available at: http://www.ohchr.org/EN/Issues/ Development/GoodGovernance/Pages/GoodGovernanceIndex.aspx (accessed: 26 April 2021).

18. $\operatorname{OECD}(\mathrm{n} / \mathrm{d})$. Directorate for Public Governance and Territorial Development. Principal Elements of Good Governance. Available at: http://www.oecd.org/governance/regulatorypolicy/irrc.htm (accessed: 26 April 2021).

19. Ping, Yu Ke. (2000). Governance and Good Governance. Beijing, China: Chinese Social Sciences Press.

20. Sheng, Chen Guang. (2007). Towards Good Governance. Zhejiang, China: Zhejiang University Press.

21. United Nations ESCAP. What is Good Governance? Available at: https://www.unescap.org/ sites/default/files/good-governance.pdf (accessed: 26 April 2021).

22. Wolfowitz, P. (2006). Good Governance and Development: A Time for Action. A speech given in Jakarta, on April 11. Strengthening the World Bank Group Engagement on Governance and Anticorruption. World Bank. 